\title{
AKURASI PENGUKURAN TEKANAN VENA SENTRAL (Central Venous Pressure)
}

\author{
Hendy Lesmana ${ }^{1}$ \\ 1.Jurusan Keperawatan Fakultas Ilmu Kesehatan Universitas Borneo Tarakan \\ *E-mail: hendylesmana2@gmail.com
}

\begin{abstract}
Abstrak
Pemantauan tekanan vena sentral merupakan salah satu metode pengukuran hemodinamik pasien secara invasif yang penggunaannya secara luas di temukan terutama di ruang perawatan intensif. Terdapat banyak faktor yang mempengaruhi akurasi pengukuran tekanan vena sentral tersebut yang dapat menyebabkan bias (penurunan/peningkatan) dari nilai sebenarnya dan hal ini dapat berdampak terhadap kesalahan dalam pengambilan keputusan klinik terhadap pasien. Metode yang digunakan pada tinjauan literatur ini menggunakan studi pencarian sistematis database terkomputerisasi (CINAHL, ProQuest dan Google cendekia) dalam bentuk jurnal penelitian yang berjumlah 14 jurnal, studi kepustakaan meliputi; Text Book, Buku ajar dan buku cetak lainnya dengan jumlah 5 buku serta Tesis hasil penelitian yang tersimpan dalam perpustakaan dengan jumlah 1 buah. Hasil studi menunjukan Akurasi Pengukuran tekanan vena sentral dipengaruhi oleh berbagai faktor, diantaranya: faktor peralatan; tersumbatnya kateter dan ujung kateter berada di ventrikel kanan, faktor kemampuan perawat; kalibrasi yang tidak benar, proses pengukuran tidak konsisten, osilasi pernafasan, tehnik pengukuran yang tidak benar serta penggunaan mode PEEP pada pasien yang terpasang ventilator. Perawat harus melakukan pemantauan tekanan vena sentral secara serial hal ini berguna dalam memantau respon pasien terhadap pengobatan/tindakan yang telah diberikan. Penting untuk diingat bahwa nilai tekanan vena sentral tinggi mungkin terkait dengan patofisiologi penyakit dan tidak selalu menunjukan overload cairan.
\end{abstract}

Kata Kunci: Akurasi hasil pengukuran, Hemodinamik invasif, Pemantauan serial, Tekanan vena sentral

\begin{abstract}
Accuracy of Central Venous Pressure Measurement. The observation of central venous pressure is one of hemodynamic measurement methods treated to patient invasively that has been widely applied in intensive care unit. There are many factors affected the accuracy of central venous pressure measurement which is able to cause bias (decrease/ increase) from actual data, and they may cause mistakenly clinical decision to patient. Method applied in this literature review is computerized systematic database searching study (CINAHI, ProQuest and Google) in journal research form as many as 14 journals, library study covering: Text book, 5 other books, and 1 thesis from library. The result of study indicates that the accuracy of central venous pressure measurement is influenced by several factors for instance: equipment factor; catheter clogged and catheter's tip on right ventricle, Nurse Capability factor; error in calibrating, inconsistency on measurement process, respiratory oscillation, error in measuring and utilizing PEEP mode on patient with ventilator. Nurse should observe the central venous pressure serially to monitor the patient respond the examination / medication treated. It is intensely important to ensure that the high rate of central venous pressure could have something to do with pathophysiology of disease and show fluid overload infrequently.
\end{abstract}

Keywords: Measurement accuracy result, Hemodinamic invasive, Serial observation, central venous pressure. 


\section{Pendahuluan}

Central Venous Pressure (CVP) atau tekanan vena sentral merupakan salah satu metode pemantauan hemodinamik yang bersifat invasif. CVP sering digunakan di ruang perawatan intensif terutama pada pasien yang mengalami gangguan keseimbangan cairan, gagal jantung, evaluasi terhadap respon terapi dan media pemberian terapi atau cairan hipertonik. Di Inggris sekitar 200.000 kateter vena sentral dipasang (diinsersi) setiap tahunnya (Jevon \& Ewens, 2009), demikian pula di Indonesia walaupun secara statistik tidak ada data yang pasti menyebutkan jumlah insersi kateter vena sentral setiap tahunnya, namun tindakan pemasangan kateter vena sentral sering ditemukan terutama di ruang perawatan intensif seperti Intensif care unit, Cardiovaskuler Care Unit, High Care Unit, Intermediate Care Unit, sehingga diharapkan bagi perawat yang bertugas di ruang perawatan intensif memiliki Pengetahuan dan Keterampilan yang baik dalam hal pengukuran dan pemantauan tekanan vena sentral.

Pemantauan tekanan vena sentral dapat bermanfaat dalam menilai fungsi jantung, volume darah yang bersirkulasi, tonus vaskular dan respon pasien terhadap terapi. Namun demikian pengukuran tekanan vena sentral dapat dipengaruhi sejumlah faktor yang dapat membiaskan hasil pengukuran (meningkat/menurun dari nilai sebenarnya), diantaranya adalah penggunaan obat vasopresor, gravitasi (posisi pasien), faktor alat (kateter tersumbat dan lokasi ujung kateter yang tidak tepat), faktor kesalahan pengukuran (kalibrasi yang tidak benar dan prosedur pengukuran yang tidak konsisten dan osilasi pernafasan) dan pada pasien yang terpasang ventilator (terutama mode Positive End Ekspiratory Pressure).

Hal-hal yang dapat mempengaruhi akurasi hasil pengukuran tekanan vena sentral tersebut bila tidak diketahui secara baik oleh perawat yang bertugas di ruang intensif dapat menyebabkan kesalahan dalam pengukuran sehingga berdampak pada pengambilan tindakan atau pengambilan keputusan klinis pasien. Kesalahan dalam pengambilan tindakan/keputusan klinis berdampak pada kondisi klinis pasien, sehingga dapat memperberat kondisi pasien yang sebenarnya telah berada dalam kondisi yang kritis. Berdasarkan uraian di atas maka penulis tertarik ingin membahas mengenai "Faktor - faktor yang mempengaruhi akurasi pengukuran tekanan vena sentral" terutama dilakukan pada pasien kritis. 
Landasan Teori Tekanan Vena Sentral.

Tekanan Vena sentral (CVP) mencerminkan tekanan pengisian atrium kanan atau preload ventrikel kanan dan bergantung pada volume darah, tonus vaskuler dan fungsi jantung. Pemantauan tekanan vena sentral dapat bermanfaat dalam menilai fungsi jantung, volume darah yang bersirkulasi, tonus vaskuler, dan respon pasien terhadap terapi. Namun demikian tekanan vena sentral dapat dipengaruhi oleh sejumlah faktor sehingga sebaiknya diinterpretasikan dalam kombinasi dengan pengukuran sistemik lainnya.

Tekanan vena sentral ditentukan oleh empat kompenen, yaitu: volume darah, fungsi kardiak, tekanan intratorakal dan tonus vasomotor. Barbeito \& Mark (2006), beberapa faktor yang mempengaruhi volume darah dan fungsi kardiak yang ikut mempengaruhi tekanan pada atrium kanan, yakni:

1. Fungsi ventrikel yang mengalirkan darah keseluruh tubuh. Dalam keadaan fungsi sistolik dan diastolik yang normal, ventrikel dapat menerima cairan yang besar tanpa adanya peningkatan tekanan vena sentral namun bila fungsinya menurun pemberian cairan walaupun sedikit mengakibatkan tekanan vena sentral meningkat secara signifikan.
2. Volume darah yaitu sekitar dua pertiga dari volume darah berada di sistem vena. Penurunan volume darah pada berbagai keadaan atau dehidrasi maka tekanan vena sentral dapat menurun.

3. Gravitasi yaitu apabila seseorang berdiri maka aliran vena lebih banyak didistribusikan ke vena ekstremitas bawah sehingga tekanan vena sentral akan menurun sedangkan pada posisi berbaring akan terjadi hal sebaliknya.

4. Tonus vena verifer yaitu vena kontriksi yang terjadi pada saat olah raga, stress, perdarahan, syok dan gagal jantung akan meningkatkan tekanan vena sentral. Sebaliknya pada suhu yang panas terjadi venodilatasi dan tekanan vena sentral akan menurun.

5. Pompa otot skeletal yaitu pada saat olah raga otot akan memompa vena di ekstremitas dan akan mendorong aliran balik ke jantung, hal ini akan meningkatkan tekanan vena sentral dan volume sekuncup saat olah raga, sebaliknya bila seseorang berdiri dan diam maka tidak ada pompa ke vena dan aliran balik ke jantung berkurang mengakibatkan curah jantung berkurang.

Tekanan intratorakal di pengaruhi oleh beberapa faktor diantaranya osilasi pernafasan, dimana saat inspirasi tekanan intratorakal menjadi lebih negatif dan 
tekanan intra abdominal lebih positif, hal ini akan meningkatkan beda tekanan yang juga meningkatkan pengisian dari vena sentral. Sebaliknya dalam keadaan ekspirasi tekanan di sekeliling jantung hampir sama dengan tekanan atmosfir sehingga aliran balik vena berkurang. Tekanan intratorakal juga dapat dipengaruhi pada pasien yang terpasang ventilator terutama penggunaan mode PEEP. Tonus vaskuler dapat dipengaruhi oleh pemberian obat vasopresor yang akan menyebabkan vasokontriksi sehingga akan menunjukan peningkatan CVP. Pada kondisi ini volume darah tidak bertambah tetapi pembuluh menjadi lebih kecil.

Hinds dan Watson (1996) yang dikutip oleh Jevon P, Ewens B \& Pooni JS (2009), mengidentifikasi masalahmasalah pada pemantauan tekanan vena sentral, yang berkaitan dengan alat \& tehnik pengukuran CVP, yakni:

1. Kateter yang tersumbat; keadaan ini akan menghasilkan pembacaan yang persisten tinggi dengan gambar yang mendatar.

2. Kalibrasi yang tidak benar, jika menggunakan tranduser dan osiloskop, makasistem harus dikalibrasi sesuai rekomendasi pabrik yang tercantum dalam petunjuk manual penggunaan alat.
3. Prosedur pengukuran yang tidak konsisten; pastikan prosedur dilakukan dengan konsisten (posisi pasien dan titik referensi yang identik) untuk pengukuran tekanan vena sentral serial.

4. Infus yang terus diberikan; pengukuran tekanan vena sentral yang tinggi palsu akan menyebabkan infus terus diberikan melalui kateter CVP selama prosedur. Selain itu cairan infus mengandung obat vasoaktif, maka resultan pembilasan dapat menyebabkan periode mendadak instabilitas jantung. Infus harus dimatikan selama dilakukan pengukuran CVP.

5. Ujung kateter berada di ventrikel kanan; keadaan ini akan menyebabkan pembacaan tekanan tinggi yang tidak diharapkan.

6. Osilasi pernafasan; pengukuran harus dilakukan pada akhir ekspirasi, terutama jika pasien mengalami distres pernafasanatau sedang diventilasi karena CVP akan menjadi lebih tinggi secara artifisial akibat tekanan intratoraks yang positif.

\section{Metode}

Studi ini merupakan suatu tinjauan $\begin{array}{lrrr}\text { literatur } & \text { (Literature } & \text { Review) yang } \\ \text { mencoba } & \text { menggali } & \text { lebih banyak } \\ \text { informasi } & \text { mengenai } & \text { hal-hal yang }\end{array}$ 
mempengaruhi nilai hasil pengukuran tekanan vena sentral (CVP) baik dari sisi keperawatan maupun dari sisi medis. Sumber untuk melakukan tinjauan literatur ini meliputi studi pencarian sistematis database terkomputerisasi (CINAHL, ProQuest dan Google cendekia) bentuk jurnal penelitian yang berjumlah 14 jurnal, studi kepustakaan meliputi; Text Book, Buku ajar dan buku cetak lainnya dengan jumlah 5 buku serta Tesis hasil penelitian yang tersimpan dalam perpustakaan (yang tidak dipublikasikan) sebanyak 1 buah dengan waktu tinjauan literatur antara tahun 1996 sampai dengan tahun 2012.

\section{Hasil}

Faktor-faktor yang mempengaruhi hasil pengukuran tekanan vena sentral adalah:

1. Lokasi insersi kateter vena sentral.

Tekanan vena sentral adalah istilah yang digunakan untuk menggambarkan tekanan dalam pembuluh darah besar yang memasok aliran balik vena ke sisi kanan jantung. Vena yang membawa aliran balik dari kepala, leher, lengan serta dada bagian atas bersatu untuk membentuk Vena Cava Superior (SVC), sedangkan pembuluh darah yang membawa aliran balik vena dari kaki, perut dan dada bagian bawah menyatu membentuk Vena Cava Inferior (IVC). Kedua vena cava ini berada dalam kesinambungan dengan atrium kanan sehingga tekanan pada vena cava ini sama dengan tekanan pada atrium kanan (RAP), sehingga Tekanan vena sentral sama dengan tekanan di atrum kanan $(\mathrm{CVP}=\mathrm{RAP})$. Hal ini dibuktikan dengan penelitian Chait, dkk yang dikutip oleh Peterson JK (2012), mencoba membandingkan tekanan vena sentral yang diukur melalui kanulasi pada vena femoralis yang ujung kanulenya bermuara di vena cava inferior dengan kateter atrium transthoracic langsung, diperoleh hasil penelitian bahwa hasil pengukuran tekanan vena sentral pada vena femoralis dengan kateter atrium menunjukan perbedaan yang tidak signifikan secara klinis walaupun secara statistik tidak identik. Murdoch, et.al. (2012), meneliti perbedaan tekanan vena sentral antara kanulasi dari vena cava superior, atrum kanan dan vena cava inferior melalui vena femoralis, sekali lagi tidak menemukan perbedaan antara ketiga situs tersebut. Jadi dapat dikatakan bahwa lokasi penusukan kateter tidak mempunyai pengaruh terhadap nilai pengukuran tekanan vena sentral.

2. Pengukuran pada setiap lumen kateter vena sentral. 
Scott (1998), meneliti mengenai perbedaan pengukuran tekanan vena sentral pada setiap lumen dari kateter trilumen pada 48 pasien dewasa di unit perawatan intensif. Hasil penenlitian menunjukan bahwa terdapat perbedaan nyata nilai tekanan vena sentral antara masing-masing lumen. Analisis lebih lanjut perbedaan antara distal port, medial dan proksimal port itu $1,12 \mathrm{mmHg}$ dan $1,28 \mathrm{mmHg}$ yang secara statistik berbeda namun secara klinis tidak signifikan. Perbedaan antara port distal dengan port medial secara klinis signifikan dalam 12,5 $\%$ dan perbedaan antara pengukuran yang dilakukan pada port distal dan port proksimal secara klinis berbeda 14,6\% Hasil penelitian ini mengarah pada kesimpulan bahwa lokasi lumen (proksimal, medial dan distal) tempat pengukuran tekanan vena sentral dapat mempengaruhi hasil pengukuran tekanan vena sentral sehingga demi keamanan mereka merekomendasikan pemantauan tekanan vena sentral dilakukan melalui port proksimal.

3. Tonus vaskuler.

CVP (tekanan vena sentral) juga dipengaruhi oleh tonus vaskuler, derajat penyempitan atau pelebaran pembuluh darah. Jika vena mengalami vasodilatasi maka darah akan terkumpul di sirkulasi perifer dan darah kembali kejantung akan berkurang, hal ini akan menyebabkan penurunan tekanan vena sentral, hal ini umunya terjadi pada pasien dengan demam, sepsis, syok anafilaksis dan pasien yang mendapatkan obat vasodilator. Pemberian obat vasokonstriksi menyebabkan peningkatan aliran darah kembali ke jantung sehingga dapat meningkatkan tekanan vena sentral. Vasokontriksi paling umum terjadi pada pasien hipotermia, hipovolemia dan pasien yang mendapatkan terapi vasodilator (Scales, 2010). Hal yang dapat dilakukan oleh perawat adalah dalam pemberian obat vasokontriktor/ vasodilator gunakan line atau jalur lain (melalui infus), bila tetap memberikan obat pada salah satu port pada kanule vena sentral maka hentikan terlebih dahulu sebelum melakukan pengukuran tekanan vena sentral (Jevon \& Ewens, 2008).

4. Garvitasi atau perubahan posisi tubuh pasien.

Gravitasi/Posisi tubuh pasien saat dilakukan pengkuran tekanan vena sentral berpengaruh terhadap hasil pengukuran. Penelitian yang dilakukan oleh Nakao S, et.al. yang dikutip oleh Arthur M, et.al. (2008) bahwa posisi tubuh telah terbukti mempengaruhi diameter, luas dan bentuk dari vena cava inferior dan ini secara tidak langsung dapat mempengaruhi tekanan vena sentral. Penelitian Arthur M, et.al. 
(2008) ingin membuktikan pengaruh diameter vena cava inferior terhadap tekanan vena sentral dimana didapatkan hasil terdapat korelasi antara tekanan vena sentral dengan diameter vena cava inferior pada pasien dengan ejeksi fraksi normal. Penelitian yang dilakukan oleh Pasion M, et.al. (2010), yang menempatkan pasien pada posisi supinasi dan posisi head of the bed, dimana terdapat 2 pasien dari 46 pasien pengamatan yang mengalami peningkatan tekanan vena sentral lebih dari $4 \mathrm{mmHg}$ dari nilai sebelumnya. Sebagai perawat yang bekerja di ruang intensif untuk membantu memastikan validitas pengukuran dan keakuratan interpretasi tekanan vena sentral maka posisi pasien harus konstan (jika mungkin dalam posisi terlentang) dan harus menggunakan titik phlebostatik yang sama (mid aksila ICS 4) untuk setiap pembacaan (Jevon P \& Ewens B, 2008). Bila posisi terlentang tidak memungkinkan maka dapat dilakukan pada posisi semifowler dengan lavelling harus dilakukan setiap kali posisi pasien berubah (Cole E, 2007).

5. Tekanan Intratorakal.

Tekanan intratoracic berpengaruh terhadap nilai pengukuran tekanan vena sentral, nilai tekanan vena sentral dapat meningkat akibat peningkatan tekanan intratoracic yang disebabkan oleh embolus paru atau ventilasi mekanik (Jarman H, 2007). Penelitian yang dilakukan oleh Mulyati T (2011), dimana pasien yang terpasang ventilator dengan mode Positive End Ekspiratory Pressure (PEEP) $5 \mathrm{~cm} \mathrm{H}_{2} \mathrm{O}, 10 \mathrm{~cm} \mathrm{H}_{2} \mathrm{O}$ dan $15 \mathrm{~cm}$ $\mathrm{H}_{2} \mathrm{O}$, kemudian dilihat pengaruhnya terhadap hasil pengukuran tekanan vena sentral. Hasil penelitian membuktikan dimana terdapat perubahan nilai tekanan vena sentral dari PEEP $5 \mathrm{~cm} \mathrm{H}_{2} \mathrm{O}$ ke PEEP $10 \mathrm{~cm} \mathrm{H}_{2} \mathrm{O}$ dengan rerata $2 \mathrm{~cm} \mathrm{H}_{2} \mathrm{O}$ (dengan hasil uji ANOVA $p=0,028$ ) dan PEEP $10 \mathrm{~cm} \mathrm{H}_{2} \mathrm{O}$ ke PEEP $15 \mathrm{~cm} \mathrm{H}_{2} \mathrm{O}$ dengan rerata 2,148 $\mathrm{cm} \mathrm{H}_{2} \mathrm{O}$ (dengan hasil uji ANOVA $p=0,016$ ). Dengan demikian semakin tinggi PEEP diberikan maka semakin mempengaruhi hasil pengukuran Tekanan vena sentral. Yang dapat dilakukan oleh perawat untuk meminimalkan pengaruh PEEP bila hendak melakukan pengukuran tekanan vena sentral adalah bila pasien terpasang ventilator dengan mode PEEP maka perawat dapat menurunkan PEEP tersebut pada tekanan $5 \mathrm{~cm} \mathrm{H}_{2} \mathrm{O}$ kemudian tunggu beberapa saat (minimal 2 menit periode equilibrium) baru dilakukan pengukuran tekanan vena sentral dan setelah pengukuran selesai maka dapat dinaikkan lagi setting PEEP ke tekanan semula. Jika terdapat kondisi medis yang tidak memungkinkan merubah tekanan PEEP 
pada setting ventilator maka dapat dilakukan pengukuran tekanan vena sentral secara serial untuk melihat perkembangan dan divalidasi dengan kondisi pasien, urin output dan tandatanda vital (tekanan darah, nadi dan pernafasan).

Tekanan vena sentral bukan indikator yang dapat diandalkan pada kasus gagal jantung kiri. Gagal ventrikel kiri meningkatkan tekanan pengisian di sisi kiri jantung, akhirnya peningkatan tekanan ini mengakibatkan aliran balik darah ke dalam vaskuler paru. Edema paru muncul pada waktu tekanan vena sentral meningkat (Kidd PS, Sturt PA\& Fultz J, 2011). Kewaspadaan perawat pada pasien yang mengalami gagal jantung sisi kiri adalah bila terjadi peningkatan tekanan vena sentral yang mendadak disertai bukti klinis dimana pasien sesak dan terdapat bunyi nafas tambahan maka kemungkinan pasien mengalami edema paru dan harus segera dilakukan penanganan. Perawat yang bekerja di ruang intensif perlu mengetahui bahwa tekanan vena sentral tidak dapat mengetahui secara langsung ukuran volume darah yang bersirkulasi sehingga setiap melakukan pengukuran dan didapatkan hasil yang berubah dari hasil sebelumnya maka perawat dapat membandingkan dengan nilai tekanan darah, urin output dan kondisi pengukuran lainnya. Untuk memperoleh informasi yang lengkap maka perawat harus melakukan pemantauan tekanan vena sentral secara serial dan bukan tunggal, hal ini berguna dalam memantau respon pasien terhadap pengobatan atau tindakan yang telah diberikan. Penting untuk diingat bahwa nilai tekanan vena sentral tinggi mungkin terkait dengan patofisiologi penyakit dan tidak selalu menunjukan overload cairan dan terkadang pasien mungkin masih mengalami kekurangan cairan.

Tekanan vena sentral didapat dengan cara memasang kateter vena sentral yang bersifat invasif yang memiliki resiko dan biaya yang besar dan sulit pengadaannya di daerah perifer. Bila tidak memungkinkan dilakukan pemasangan kateter vena sentral atau tidak ada alat yang mendukung untuk memasang kateter vena sentral maka dapat dilakukan estimasi tekanan vena sentral melalui tekanan intra okuler asalkan tidak terdapat kelainan pada mata yang dapat mempengaruhi tekanan intra okuler. Secara anatomi, tekanan isi bola mata berhubungan dengan vena cava superior dan bilik atrium kanan jantung. Penelitian yang dilakukan oleh Tarigan RH (2010), dimana ingin melihat hubungan antara tekanan vena sentral dengan tekanan intra okuler pada 20 
pasien yang di rawat di ruang intensif. Hasil penelitian menunjukan Korelasi linier ditemukan antara TIO dan CVP $(\mathrm{r}=0,875, \quad p=0,0001)$. CVP dapat diestimasi dengan didapatnya nilai TIO $(\mathrm{CVP}=-0,815+0,535 \times \mathrm{TIO})$.

\section{Kesimpulan}

Pemantauan tekanan vena sentral dapat bermanfaat dalam menilai fungsi jantung, volume darah yang bersirkulasi, tonus vaskular dan respon pasien terhadap terapi. Namun demikian pengukuran tekanan vena sentral dapat dipengaruhi sejumlah faktor yang dapat membiaskan hasil pengukuran, diantaranya adalah penggunaan obat vasopresor, gravitasi (posisi pasien), faktor alat (kateter tersumbat dan lokasi ujung kateter yang tidak tepat), faktor kesalahan pengukuran (kalibrasi yang tidak benar dan prosedur pengukuran yang tidak konsisten dan osilasi pernafasan) dan pada pasien yang terpasang ventilator (terutama mode Positive End Ekspiratory Pressure).

Lokasi insersi pada cateter vena sentral tidak berimplikasi klinis terhadap hasil pengukuran tekanan vena sentral. Penelitian Murdoch, et.al. yang dikutip oleh Peterson. JK (2012), tidak menemukan perbedaan antara ketiga lokasi kanulasi yakni; vena cava superior, atrium kanan dan vena cava inferior pada nilai pengukuran tekanan vena sentral. Pada penggunaan kateter CVP trilumen terdapat perbedaan pengukuran tekanan vena sentral pada masing-masing lumen tersebut, dimana antara lumen distal dan medial terdapat perbedaan $1,12 \mathrm{mmHg}$ dan pengukuran pada lumen distal ke lumen proksimal terdapat perbedaan 1,28 $\mathrm{mmHg}$.

Nilai pengukuran tekanan vena sentral juga dipengaruhi oleh aktivitas tonus vaskuler dimana bila vena mengalami vasodilatasi maka terjadi penurunan tekanan vena sentral sebaliknya bila vena mengalami vasokontriksi maka terjadi peningkatan tekanan vena sentral.

Gravitasi/posisi tubuh juga berpengaruh terhadap hasil pengukuran tekanan vena sentral, dimana posisi tubuh telah terbukti mempengaruhi diameter, luas dan bentuk dari vena cava inferior. Untuk membantu validitas dan keakuratan hasil penenlitian maka sebaiknya pasien harus pada posisi konstan dan harus menggunakan titik plebostatik yang sama setiap pengukuran.

Tekanan intratoracic berpengaruh terhadap nilai tekanan vena sentral terutama pada pasien yang terpasang ventilator dengan modus Positive End Ekspiratory Pressure (PEEP). Semakin besar tekanan PEEP yang diberikan 
kepada pasien maka semakin besar perubahan nilai tekanan vena sentral pasien.

Tekanan vena sentral tidak dapat menentukan secara langsung volume darah bersirkulasi sehingga dalam pengukurannya harus divalidasi dengan pengukuran yang lain, seperti: tekanan darah, nadi, pernafasan dan output urin. Perawat perlu mewaspadai terhadap peningkatan tekanan vena sentral yang mendadak disertai tanda klinis lainnya seperti; sesak nafas dan terdapat bunyi nafas tambahan maka kemungkinan pasien mengalami edema paru dan harus segera dilakukan penanganan.

Penelitian yang dilakukan oleh Tarigan. RH (2010), menemukan hubungan yang signifikan antara tekanan vena sentral dengan tekanan intraokuler, hasil penelitian menunjukan Korelasi linier ditemukan antara TIO dan CVP $(\mathrm{r}=0,875, \quad p=0,0001) . \quad$ CVP dapat diestimasi dengan didapatnya nilai TIO $(\mathrm{CVP}=-0,815+0,535 \times$ TIO $)$. Metode ini dapat diterapkan bagi rumah sakit perifer yang tidak memiliki sarana dan prasarana untuk dilaakukan pemasangan kateter vena sentral juga pada pasien yang tidak memungkinkan secara klinis untuk dilakukan pemasangan kateter vena sentral.

\section{Rekomendasi}

Diharapkan banyak lagi penelitian yang mengarah pada keakuratan hasil pengukuran tekanan vena sentral terutama yang berbasis evidance base. Banyak kendala yang dihadapi di lahan praktik dalam menentukan keakuratan hasil pengukuran seperti kapan waktu pengukuran dilakukan pada pasien yang mengalami sesak nafas. Perubahan posisi pasien juga sering terjadi pada kegiatan pengukuran tekanan vena sentral secara series tetapi tidak diketahui secara pasti berapa perubahan tekanan vena sentral tersebut pada setiap perubahan posisi dari pasien.

Berdasarkan uraian singkat diatas kiranya perawat yang berkerja di ruang rawat intensif dapat memahami kondisikondisi yang dapat mempengaruhi hasil pengukuran tekanan vena sentral sehingga dapat menggali lebih lanjut fenomenafenomena lain di lapangan yang kiranya dapat menjadi masukan bagi peneliti keperawatan untuk dapat memberikan kontribusi bagi kemajuan perkembangan ilmu keperawatan.

\section{Referensi}

Ahrens, T. (2010). Stroke volume optimization versus central venous pressure in fluid management. American Association of Critical Care Journals. Diperoleh dari 
http://web.ebscohost.com/ehost/pdf viewer/pdfviewer?sid=3cfa6966-

a2d2-49f5-989a-

caa0f00a98ce\%40sessionmgr12\&vi $\mathrm{d}=22 \&$ hid $=19$.

Arthur, ME. landolfo, C. Wade, M. \& Castresana. (2009). Inferior vena cava diameter (IVCD) measured with transesophageal echocardiography (TEE) can be used to derive the central venous pressure (CVP) in anesthetized mechanically ventilated patients. Journal of CV Ultrasound \& Allied Tech. Diperoleh dari http://web.ebscohost.com/ehost/pdf viewer/pdfviewer?sid=3cfa6966a2d2-49f5-989acaa0f00a98ce\%40sessionmgr12\&vi $\mathrm{d}=5$ \&hid $=19$.

Barbeito, A. \& Mark, JB. (2006). Arterial and Central Venous Pressure Monitoring. Anesthesiology Clin.

Cole, E. (2007). Measuring central venous pressure, art \& science clinical skills. Nursing Standard Journals. Diperoleh dari http://web.ebscohost.com/ehost/pdf viewer/pdfviewer?sid=3cfa6966a2d2-49f5-989acaa0f00a98ce\%40sessionmgr12\&vi $\mathrm{d}=22 \&$ hid $=19$.

Delemos, et.al. (2011). Use of Peripherally Inserted Central Catheters as an Alternative to Central Catheters in Neurocritical Care Units. Critical Care Nurse Journals. Diperoleh dari http://web.ebscohost.com/ehost/pdf viewer/pdfviewer?sid=3cfa6966a2d2-49f5-989acaa0f00a98ce\%40sessionmgr12\&vi $\mathrm{d}=22 \&$ hid $=19$.
Hinghofer-szalkay \& Helmut. (2011). Gravity, the hydrostatic indifference concept and the cardiovascular system. Eur Journals Appl Physiol. Diperoleh dari http://search.proquest.com/docview /835125183/fulltextPDF/137EA67 F6D0420E5340/9? accountid=3862 8.

Hudak, CM. \& Gallo, BM. (2010). Keperawatan Kritis Pendekatan Holistik. Volume 1. Edisi 6 (Ester, M. Kariasa, M. Sumarwati, M \& Afifah, E.Penerjemah). Buku Asli diterbitkan Tahun 1994. Philadelphia. USA. J.B. Lipincott Company.

Jarman, H. (2007). Invasive haemodynamic monitoring: the role of emergency nurses in helping to provide critical care. Journals Emergency Nurse. Diperoleh dari http://web.ebscohost.com/ehost/pdf viewer/pdfviewer?sid=3cfa6966a2d2-49f5-989acaa0f00a98ce\%40sessionmgr12\&vi $\mathrm{d}=23$ \&hid $=19$.

Jevon, P. Ewens, B. \& Pooni, JS. (2009). Pemantauan Pasien Kritis. Edisi ke II. (Umami, V. Penerjemah). Buku Asli diterbitkan Tahun 2007. UK. Blackwell Publishing Ltd.

Joynt, GM, Gomersall, CD, \& Buckley, AT, (1996). Comparison of intrathoracic and intra-abdominal measurements of central venous pressure. ProQuest Biology Journals. Diperoleh dari http://search.proquest.com/docview /199022597/fulltextPDF/137EA5F $6 \mathrm{EBB} 40 \mathrm{E} 285 \mathrm{CF} / 1$ ? accountid $=386$ 28. 
Kidd, PS. Sturt, PA. \& Fultz, J. (2011). Pedoman Keperawatan Emergensi. (Ester, M \& Yulia, Penerjemah). Buku Asli Diterbitkan Tahun 2000, Lexington. Kentucky. Mosby. Inc.

Milton, S. (2009). Circulation and invasive monitoring: back to basics. Open Learning Zone Journals. Diperoleh dari http://web.ebscohost.com/ehost/pdf viewer/pdfviewer?sid=3cfa6966a2d2-49f5-989acaa0f00a98ce\%40sessionmgr $12 \& v i$ $\mathrm{d}=23 \&$ hid $=19$.

Mulyati, T. (2011). Pengaruh PEEP (Positive End Expiratory Pressure) Terhadap Nilai CVP (Central Venous Pressure) pada Pasien Dengan Penggunaan Ventilator di Ruang GICU RSUP DR. Hasan Sadikin Bandung. (Tesis tidak dipublikasikan). Universitas Padjadjaran, Bandung, Indonesia.

Pasion, E. et.al. (2010). Evaluation of The Monitor Cursor-Line Methode for Measuring Pulmonary Artery and Central Venous Pressures. American Journals of Critical Care. Diperoleh dari http://web.ebscohost.com/ehost/pdf viewer/pdfviewer?sid=3cfa6966a2d2-49f5-989acaa0f00a98ce\%40sessionmgr12\&vi $\mathrm{d}=22 \&$ hid $=19$.

Peterson \& Kristine, J. (2012). Ask the Experts. Measuring Central Venous Pressure with a Triple-Lumen Catheter. Critical Care Nurse Journals. Diperoleh dari http://web.ebscohost.com/ehost/pdf viewer/pdfviewer?sid=3cfa6966a2d2-49f5-989a- caa0f00a98ce\%40sessionmgr12\&vi $\mathrm{d}=9$ \&hid $=19$.

Puri, GD. Agarwal, J. Solankia, A. \& Rana, SS. (2008). Cerebral venous congestion during cardiopulmonary bypass: role of bispectral index monitoring. Perfusion Journals. Diperoleh dari http://web.ebscohost.com/ehost/pdf viewer/pdfviewer?sid=3cfa6966a2d2-49f5-989acaa0f00a98ce\%40sessionmgr12\&vi $\mathrm{d}=5$ \&hid $=19$.

Scales. (2010). Central venous pressure monitoring in clinical practice. Nursing Standard Journals. Diperoleh dari http://web.ebscohost.com/ehost/pdf viewer/pdfviewer?sid=3cfa6966a2d2-49f5-989acaa0f00a98ce\%40sessionmgr12\&vi $\mathrm{d}=5$ \&hid $=19$.

Scott, SS. et.al. (1998). Influence of Port Site On Central Venous Pressure Measurements from Triple-lumen Catheters In Critically Ill Adults. Am J Critical Care. Diperoleh dari https://www.ncbi.nlm.nih.gov/pub med/9429684.

Tarigan, RH. 2010. Hubungan Tekanan Vena Sentral dengan Tekanan Intra Okuli Menggunkanan Tonometer Schiotz Pada Pasien di Ruang Intensif. Universitas Sumatra Utara. Tesis. Program Pendidikan Dokter Spesialis Anestesi. Universitas Sumatra Utara. Diperoleh dari http://repository.usu.ac.id/bitstream /123456789/22996/6/Abstract.pdf.

Van Waes, OJF. et.al. (2009). A singlelumen central venous catheter for continuous and direct intraabdominal pressure measurement. European Journals of Trauma and Emergency Surgery. Diperoleh dari http://web.ebscohost.com/ehost/pdf 
viewer/pdfviewer?sid=3cfa6966-

a2d2-49f5-989a- caa0f00a98ce\%40sessionmgr12\&vi $\mathrm{d}=20$ \&hid $=19$. 